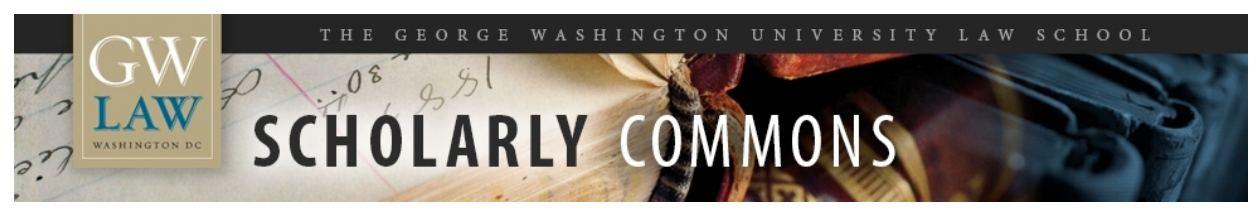

\title{
International Judicial Bodies for Resolving Disputes Between States
}

\section{Sean D. Murphy}

George Washington University Law School, smurphy@law.gwu.edu

Follow this and additional works at: https://scholarship.law.gwu.edu/faculty_publications

Part of the Law Commons

\section{Recommended Citation}

Sean D. Murphy, International Judicial Bodies for Resolving Disputes Between States in OXFORD HANDBOOK ON INTERNATIONAL ADJUDICATION (Cesare Romano et al. eds., Oxford University Press) (forthcoming).

This Chapter is brought to you for free and open access by the Faculty Scholarship at Scholarly Commons. It has been accepted for inclusion in GW Law Faculty Publications \& Other Works by an authorized administrator of Scholarly Commons. For more information, please contact spagel@law.gwu.edu. 


\title{
INTERNATIONAL JUDICIAL BODIES FOR RESOLVING DISPUTES BETWEEN STATES
}

\author{
in OXFORD HANDBOOK ON INTERNATIONAL ADJUDICATION \\ (Cesare Romano et al. eds.) (Oxford U niversity Press) (forthcoming) \\ Sean D. M urphy \\ George W ashington University Law School
}

\section{I) INTRODUCTION}

This chapter assesses those international judicial bodies that are established principally to resolve disputes between States, notably the International Court of J ustice (ICJ), the International Tribunal for the Law of the Sea (ITLOS) and the World Trade Organization (WTO) A ppellate B ody. Unlike courts oriented toward regional economic integration or regional human rights, such as the European Court of J ustice or the Inter-A merican Court of Human Rights, these courts and tribunals primarily focus on resolving disputes between States. Contentious cases before these bodies, for the most part, do not involve institutional organs or other non-State actors as litigants. Unlike international criminal courts, these courts focus exclusively on issues of State responsibility, generally finding that international law has or has not been violated; if a violation is found, matter is usually negotiated to a resolution by the concerned States. A Ithough reparation in the form of restitution, compensation or satisfaction is possible, criminal sanctions are not. Unlike ad hoc arbitral tribunals formed to address matters of investment or commerce, such as under the auspices of the International Centre for the Settlement of Investment Disputes (ICSID) or the International Chamber of Commerce, these judicial bodies are permanent institutions; they are designed to operate for decades, with adjudicators who serve for years on a range of cases, not for just a single claim or group of claims. Unlike processes for mediation or conciliation, these courts or tribunals issue decisions that are legally binding on the parties appearing before them.

Such international judicial bodies have a prominent place in the pantheon of international adjudication; indeed, the ICJ is often viewed - symbolically - as at the pinnacle of international adjudication. $Y$ et with the rise of numerous other dispute resolution bodies, including those before which non-State actors may appear and that may hear hundreds of cases per year, questions have arisen as to whether such 'old school' fora still play a dominant or even important role for international law, especially given the relative paucity of their caseloads. 
The various chapters in this volume demonstrate the great variety existing in the world of international adjudication. Such variety makes it difficult to regard any international dispute settlement system as purely a 'State-only' system, for even the ICJ allows non-State actors to appear before it in advisory opinion proceedings. ${ }^{1} \mathrm{~N}$ evertheless, the family of judicial bodies at issue in this chapter are generally oriented toward the resolution of disputes between States and may be regarded as sharing certain common elements, ${ }^{2}$ which will be briefly discussed in this section by reference to the ICJ, the ITLOS and the WTO A ppellate Body.

\section{1) Establishment by International A greement/G overned by International L aw}

The first key element common to these international judicial bodies is that they are established by means of a multilateral treaty adopted by States. The ICJ was created in 1945 pursuant to the U.N. Charter ${ }^{3}$ and the ICJ Statute. ${ }^{4}$ It was preceded by the League of Nations' Permanent Court of International J ustice (PCIJ), with which it has considerable continuity. The ITLOS was created by the 1982 U.N. Convention on the Law of the Sea. ${ }^{5}$ The WTO Appellate B ody was created by the 1994 U ruguay R ound U nderstanding on R ules and Procedures G overning the Settlement of Disputes, ${ }^{6}$ though it was preceded by a dispute resolution process that existed for decades under General A greement on Tariffs and Trade (GATT).

Such judicial bodies are governed by, and apply in their decision-making, international law. The ICJ famously applies four classic sources of international law: treaties, custom, general principles and, on a subsidiary basis, judicial decisions and the writing of publicists. ${ }^{7}$ The ITLOS

\footnotetext{
*INSERT BIBLIOGRAPHICAL INFORMATION

${ }^{1}$ See, CPR R omano, 'The Proliferation of International J udicial B odies: The Pieces of the Puzzle' (1999) 31 N.Y.U.J. Int'l L. \& Pol. 709, 739.

${ }^{2}$ Regional judicial bodies share some of these elements, including the Caribbean Court of Justice, the Central A merican Court of J ustice, the Court of Justice for the Common M arket of Eastern and Southern A frica and the European Court of J ustice. $Y$ et such courts typically have inter-State dispute resolution as just one component of their jurisdiction, with further possibilities for jurisdiction over disputes with non-State actors or appeals of decisions reached in national court systems. Even so, the analysis set forth in this chapter is relevant for understanding the use of such other courts and tribunals in respect to their jurisdiction to address disputes between States. N on-judicial bodies, such as some of the committees established under human rights treaties, can also hear disputes between States, though to date such disputes have not been brought before those committees.

${ }^{3}$ Charter of the U nited Nations 1945, A rts. 7.1, 92-96, 59 Stat. 1031, 1 U.N.T.S XVI (U.N. Charter).

${ }^{4}$ Statute of the International Court of J ustice 1945, 59 Stat. 1055, 33 U .N ,T.S. 933 (ICJ Statute).

${ }^{5}$ U.N. Convention on the Law of the Sea (LOSC), A nnex VI (IT LOS Statute) 1982, 1833 U.N.T.S. 3.

${ }^{6} \mathrm{M}$ arrakesh A greement Establishing the World Trade Organization, Annex 2, Understanding on Rules and Procedures Governing the Settlement of Disputes 1994, A rt. 17, 1869 U.N.T.S. 401 (DSU).

${ }^{7}$ ICJ Statute, A rt. 38.1.
} 
applies the rules set forth in the U.N. Convention on the Law of the Sea and other rules of international law not incompatible with that Convention. ${ }^{8}$ The WTO A ppellate Body addresses 'issues of law' and 'legal interpretations' covered in WTO panel reports, ${ }^{9}$ which address the interpretation and application of certain WTO agreements ${ }^{10}$ against the backdrop of other rules of international law. ${ }^{11}$ In the course of such decision-making, it is possible that the court or tribunal will take account of rules expressed in national law if necessary when applying international law.

\section{2) Permanent Institution/Q uasi-Permanent (R epeat) Adjudicators}

These judicial bodies are permanent institutions, housed in buildings in The Hague (ICJ), Hamburg (ITLOS) or Geneva (WTO A ppellate Body), where they are supported by a permanent registry or secretariat. As such, there is a strong sense of institutional continuity, with formal and informal traditions passed along through persons who spend much, if not all, of their careers at the institution.

Each institution establishes its own rules of procedure which, although capable of being modified over time, create a relatively permanent framework of detailed rules for how cases are to be decided, often supplemented by further instruments setting forth practical guidelines. The Rules of the Court of the ICJ, which were drafted by and are periodically revised by the ICJ's judges, were thoroughly revised in 1978, although some further amendments have been made since that time. ${ }^{12}$ The ITLOS Rules of the Tribunal were drafted and revised by its judges, with the most recent version adopted in 2009. ${ }^{13}$ The WTO A ppellate B ody's W orking Procedures for A ppellate Review have been adopted and revised by the Appellate Body, in consultation with the WTO Director-General and the Chairman of the Dispute Settlement Body, most recently in 2010. ${ }^{14}$ While such rules can be modified over time to take account of changed circumstances, they are largely stable, al lowing for well-settled practice to develop. Indeed, many of the ICJ's current rules

\footnotetext{
${ }^{8}$ LOSC, A rt. 293; ITLOS Statute, A rt. 23; see, JE Noyes, 'The International Tribunal for the Law of the Sea' (1998) 32 Cornell Int'I L.J . 109, at 123-25; G Eiriksson, The International Tribunal for the Law of the Sea (M artinus Nijhoff 2000).

${ }^{9}$ DSU, A nnex 2, Art. 17.6.

${ }^{10}$ Ibid., A rts. 3.2, 7.

${ }^{11}$ See, D Palmeter and PC M avroidis, 'T he WTO Legal System: Sources of Law' (1998) 92 A m. J. Int'I L. 398, 399 (viewing DSU Article 7 'as the WTO substitute, mutatis mutandis, for A rticle 38' of the ICJ Statute).

12 International Court of J ustice, 'Rules of Court' (ICJ , 14 A pril 1978) $<$ <ttp://www.icj-cij.org/documents/index.php?p1=4\&p2=3\&p3=0> accessed $30 \mathrm{~J}$ une 2012.

${ }^{13}$ International Tribunal for the Law of the Sea, 'Rules of the Tribunal' 2009, D oc. ITL OS/8

<http://www.itlos.org/fileadmin/itlos/documents/basic_texts/ltlos_8_E_17_03_09.pdf>accessed 30 J une 2012.

${ }^{14}$ WTO A ppellate B ody W orking Procedures for A ppêllate Review $20 \overline{1} 0, \bar{D}$ oc. WT/AB/W P/6.
} 
can be traced back to the PCIJ rules first adopted in the 1920's.

The judges or members who sit on these judicial bodies are not permanent, but they are elected or appointed for relatively long-terms, during which they participate in a large number of cases, again reinforcing a culture of continuity as well as reliance on past decision-making. ${ }^{15}$ The IC) consists of 15 respected jurists from across the globe, elected for nine-year terms by the U.N. General A ssembly and U.N. Security Council. ${ }^{16}$ Five judges of the ICJ are elected every three years, ${ }^{17}$ allowing continuity of membership even amidst change, with no term limits. In fact, several judges have served more than twenty years. The Court may sit in chambers if requested by the parties appearing before it. The ITLOS consists of 21 judges elected by secret ballot of the States Parties to the LOSC, also for renewable, nine-year terms. Like the ICJ, the ITLOS terms are staggered so that one-third of the judges' terms expire every three years, and the judges may sit in chambers. ${ }^{18}$ Disputes between States as to the interpretation or application of the LOSC Part XI (on activities in the seabed 'A rea') may be submitted to either ${ }^{19}$ a special chamber of the ITLOS ${ }^{20}$ or to the ITLOS' Seabed Disputes Chamber. The latter consists of 11 of the ITLOS judges selected by majority vote but, when hearing a dispute among States, it is to form an ad hoc chamber composed of three of its members. ${ }^{21}$ The WTO A ppellate B ody consists of seven members, who are appointed for four-year terms by the WTO Dispute Settlement B ody and may be reappointed once. $^{22}$

For all three institutions, the persons are el ected or appointed based on their independence, character and expertise. These individuals are paid international civil servants; they receive no pay and take no instructions from governments, and they cannot be recalled or dismissed by the governments of their nationalities. While judges or members are precluded from sitting in a case in which they were previously involved as counsel, they are not prevented from sitting in a case simply because it involves a State of the judge's or member's nationality. Even so, the issue of nationality is not ignored. Two persons of the same nationality would not be elected or appointed

\footnotetext{
${ }^{15}$ See, E V oeten, 'T he Politics of International J udicial A ppointments' (2009) 9 Chi. J . Int'I L. 387.

${ }_{17}^{16}$ ICJ Statute, Arts. 3-4, 13.

${ }^{17}$ Ibid., A rt. 13.

${ }^{18}$ Noyes, supra note 8 , at $126-28$.

${ }^{19}$ LOSC, A rt. 188.1.

20 ITL OS Statute, Arts. 15, 17.

${ }^{21}$ Ibid., A rt. 36.

${ }^{22}$ DSU, Art. 17.2.
} 
to serve on the judicial body simultaneously and the selection processes are designed to ensure broad geographic representation. M oreover, if a State has no judge of its nationality on the ICJ or the ITLOS, then it may appoint a judge ad hoc for the purposes of its case.

\section{3) General Dominance of States/E xclusion of Non-State Actors}

States generally dominate these inter-State judicial bodies, but there are some important exceptions to that dominance. The U.N. Charter provides that the ICJ shall be the 'principal judicial organ' of the U nited Nations and that all U.N. M ember States are ipso facto parties to the IC) Statute. ${ }^{23}$ A s such, all $193 \mathrm{M}$ ember States of the U nited Nations are parties to the ICJ Statute and thus capable of appearing before the Court in either contentious cases or advisory proceedings. ${ }^{24}$

Only States may participate in contentious cases; ${ }^{25}$ this precludes contentious cases brought by or against international organizations, non-governmental organizations, transnational corporations or individuals. By contrast, written and oral pleadings have been submitted to the Court in advisory opinion proceedings by the U.N. Secretariat, by representatives from other international organizations and by 'quasi-State' entities not yet fully recognized as States and not admitted as such to the United Nations (such as representatives from Palestine ${ }^{26}$ or Kosovo ${ }^{27}$ ). While such proceedings are 'advisory' under the terms of the U.N. Charter and the ICJ Statute, sometimes the proceedings have a contentious case quality to them, such as Palestine versus Israel in the Wall case or Serbia versus K osovo in the Kosovo case. M oreover, certain treaty instruments, such as the headquarters agreement of an international organization, in essence can transform the advisory opinion into a 'decision' that is binding on the entities appearing before the Court (such as the international organization and the host State). When this happens, the phenomenon is referred to as 'binding advisory opinions' ${ }^{28}$

States al so dominate in the proceedings before the WTO A ppellate B ody but, here too, the practice is not uniform. A regional organization that has been accorded exclusive competence by

\footnotetext{
${ }^{23}$ U.N. Charter, Arts. 92, 93.1.

${ }^{24}$ States that are not U.N. members are able to adhere to the Court's Statute if they so choose. ICJ Statute, A rt. 35.2.

${ }^{25}$ ICJ Statute, Art. 34.1.

${ }^{26}$ Legal Consequences of the Construction of a Wall in the O ccupied Palestinian Territory (Advisory O pinion) [2004] I.C.J. Rep 136.

${ }^{27}$ Accordance with International Law of the U nilateral D eclaration of Independence in Respect of Kosovo (A dvisory Opinion) [2010] ICJ Rep 48.

${ }^{28}$ See, R A go, ' 'Binding' A dvisory O pinions of the International Court of J ustice' (1991) 85 A m. J. Int'I L. 439.
} 
States over matters covered by the relevant WTO agreements can appear before the A ppellate Body, as has occurred on many occasions with respect to the European Community/U nion, as both claimant and respondent. Moreover, certain non-State entities such as Hong Kong, Macau and Taiwan, can be parties to cases before the WTO A ppellate Body.

The LOSC Part XV only allows for LOSC 'States Parties' to appear before the ITLOS to resolve their disputes. Y et the LOSC defines 'States Parties' as including some actors not normally considered States. ${ }^{29}$ Thus, the European Union has appeared as a party. ${ }^{30}$ Further, natural or juridical persons may appear before ITLOS to seek the prompt release of a vessel and its crew when detained by a coastal State, though they only do so 'on behalf of' the flag State of the detained vessel (and therefore must first receive authorization from that State). ${ }^{31} \mathrm{M}$ oreover, not only may LOSC States Parties and State enterprises appear before the ITLOS Seabed Disputes Chamber to resolve disputes relating to Part XI of the Convention, but so may two entities created by the Convention - the International Seabed Authority and the Enterprise ${ }^{32}$ - as well as in certain circumstances natural or juridical persons and prospective contractors who have been sponsored by a State. ${ }^{33}$ The ITLOS' jurisdiction under agreements other than the LOSC may extend beyond a dispute between two States; its jurisdiction appears capable of allowing disputes brought consensually under other agreements by non-State actors, though no such dispute has yet been filed. ${ }^{34}$ Finally, non-State actors may appear as amicus curiae in advisory opinion proceedings, as recently occurred before the Seabed Disputes Chamber. ${ }^{35}$

\section{4) Broad and $Y$ et $L$ imited J urisdiction}

When the ICJ has jurisdiction in a contentious case, it may apply the classic sources of law identified in Article 38.1 of the ICJ Statute: treaties; customary international law; general principles of law; and judicial decisions and the teachings of the ' most highly qualified publicists

\footnotetext{
${ }^{29}$ LOSC, A rt. 1.2.2 (including in the definition self-governing associated States and territories entitled to participate in the LOSC under Article 305 and international organizations entitled to participate in the LOSC under A nnex IX ).

${ }^{30}$ See, Conservation and Sustainable Exploitation of Swordfish Stocks in the South-Eastern Pacific Ocean (Chile/E uropean U nion) <http://www.itlos.org/index.php?id=99> accessed $30 \mathrm{~J}$ une 2012.

${ }^{31}$ LOSC, A rt. 292.2.

${ }^{32}$ The International Seabed A uthority administers the resources of the deep seabed area. The Enterprise will serve as the A uthority's mining operator, but as of 2012 has not yet been established.

${ }^{33}$ LOSC, A rt. 187.

${ }^{34}$ ITLOS Statute, Arts. 20-21; LOSC, A rts. 291.2, 308; see, A E B oyle, 'Dispute Settlement and the Law of the Sea Convention: Problems of Fragmentation and Jurisdiction' (1997) 46 Int'I \& Comp. L.Q. 37 (1997), 47-54.

${ }^{35}$ Responsibilities and Obligations of States Sponsoring Persons and Entities with Respect to Activities in the Area, ITLOS Case N 0. 17 (Advisory Opinion) [2011] 50 I.L.M . 458, para. 14.
} 
of the various nations' ${ }^{36}$ Further, any State that is a Party to the Statute may consent to appear before the Court in a contentious case. A s such, the potential range of the Court's decisions is quite broad, covering all aspects of international law and all $M$ embers of the $U$ nited $N$ ations and other States that have joined the Statute. Y et a State's consent to the Court's jurisdiction does not exist simply by virtue of the State being a Party to the ICJ Statute; instead, the State must expressly consent to such jurisdiction.

There are three means by which a State can express consent to the jurisdiction of the Court. States can accept the Court's jurisdiction on an ad hoc basis for the adjudication of a dispute that has arisen. ${ }^{37}$ A Iternatively, States can conclude a bilateral or multilateral treaty that provides for future ICJ jurisdiction over certain issues in the event that a dispute arises. ${ }^{38}$ Finally, jurisdiction may arise under the 'optional clause' or 'compulsory jurisdiction' of the Court, if the two disputing States have made unilateral declarations that 'they recognize as compulsory ipso facto and without special agreement, in relation to any other state accepting the same obligation, the jurisdiction of the Court in all legal disputes ...' involving issues of law or fact governed by rules of international law. ${ }^{39}$ Of the 193 U.N. M embers, 67 have accepted the Court's compulsory jurisdiction as of mid-2012. ${ }^{40}$

In all three instances, the Court's jurisdiction will be limited by the terms as set forth in the consent granted. Thus, the treaties providing for the Court's jurisdiction are limited to the terms set forth in those treaties, while many of the declarations accepting the Court's compulsory jurisdiction contain conditions, limitations or reservations significantly limiting the State's consent. States have formulated their exceptions to the Court's jurisdiction in many ways, including carve-outs with respect to matters relating to national security, delimitation of territory or internal affairs.

Dispute settlement before the ITLOS is also potentially broad, covering most disputes on the interpretation or application of the LOSC and related treaties, ${ }^{41}$ with the potential application

\footnotetext{
${ }^{36}$ ICJ Statute, Art. 38.1.

${ }^{37}$ Ibid., A rt. 36.1.

${ }^{38}$ Idem. Treaties pre-dating the existence of the ICJ that provide for jurisdiction of the $\mathrm{PCIJ}$ are also regarded, under the ICJ Statute, as triggering ICJ jurisdiction. Ibid., Art. 37.

39 Ibid., A rt. 36.2; see, J G M errills, 'The Optional Clause Revisited' (1993) 64 B rit. Y.B. Int'I L. 197.

${ }^{40}$ For the list, see, International Court of J ustice, 'J urisdiction'

$<h t t p: / / w w w . i c j-c i j . o r g / j u r i s d i c t i o n / i n d e x . p h p ? p 1=5 \& p 2=1 \& p 3=3>$ accessed $30 \mathrm{~J}$ une 2012.

${ }^{41}$ ITLOS Statute, Art. 21; ICJ Statute, A rt. 36.1.
} 
of broader international law. ${ }^{42}$ Part XV of the LOSC provides that States Parties must select one of four options for compulsory dispute resolution when they ratify or accede to the Convention. ${ }^{43}$ One option is dispute settlement at the ITLOS under LOSC A nnex VII (to date selected by about 30 States); a second option is dispute settlement at the ICJ (selected by about 25 States); and two further options are general arbitration under LOSC A nnex VII (selected by about nine States) or specialized arbitration under LOSC A nnex VIII (selected by about nine States). ${ }^{44}$ If a State Party fails to select a forum (which is the case for most States), it is deemed to have selected A nnex VII arbitration.

When a dispute arises concerning the interpretation or application of the Convention, if two Parties to the dispute have both selected the same forum, then that forum is used to resolve the dispute, unless the Parties agree otherwise. ${ }^{45}$ If two States cannot agree on a forum, then the dispute is submitted to A nnex VII arbitration. ${ }^{46}$ Thus, the ITLOS or the ICJ is only used when the two disputing States have both selected either the ITLOS or the ICJ, or decide ad hoc to avail themselves of those forums; otherwise, the most likely scenario is for the matter to default to arbitration. Whichever forum receives the dispute, the matter is decided through application of the LOSC and other rules of international law. ${ }^{47}$ Further, as noted above, for certain disputes with respect to activities in the deep seabed under Part XI of the Convention, jurisdiction rests with the ITLOS Seabed Disputes Chamber, though two States may alternatively agree to submit their Part XI dispute to a special chamber of ITLOS or submit their contract dispute relating to Part XI to binding arbitration. ${ }^{48}$

Part XV envisages compulsory dispute settlement for most aspects of the Convention, but it excludes some important types of disputes. For example, Part XV excludes any claim that the coastal State is denying other States the freedoms and rights to which they are entitled in the

\footnotetext{
${ }^{42}$ See, e.g. M ichael W ood, 'The International Tribunal for the L aw of the Sea and General International Law' (2007) 22 Int'l J. M arine \& Coastal L. 351.

${ }^{43}$ For the LOSC dispute settlement options selected (or not selected) by the State Parties, see, U.N. O ceans \& Law of the Sea, 'Settlement of Disputes M echanism'

<http://www.un.org/Depts/los/settlement_of_disputes/choice_procedure> accessed 30 J une 2012.

${ }^{44}$ LOSC, A rt. 287.1.

${ }^{45}$ Ibid., A rt. 287.4.

${ }^{46}$ Ibid., A rt. 287.5.

${ }^{47}$ Ibid., A rt. 293.

${ }^{48}$ Ibid., A rt. 188.
} 
coastal State's exclusive economic zone (EEZ), ${ }^{49}$ or a claim regarding the coastal State's power to determine for that zone the allowable catch of fish, the coastal State's harvesting capacity and its allocation of any surplus to other States. ${ }^{50}$ Further, States are allowed to exclude additional disputes relating to the Convention, including disputes concerning maritime delimitation, military activities and disputes in respect of which the Security Council is exercising its functions. ${ }^{51}$ Though such matters fall outside the LOSC's compul sory dispute settlement, the ITLOS and the IC) remain available for consensual referral of any disputes concerning the LOSC or related agreements, as well as arising under customary international law. ${ }^{52}$

The provisions on settlement of disputes set forth in Part XV apply, mutatis mutandis, to disputes arising under agreements 'related to the purposes of the Convention', in accordance with the terms of that agreement. ${ }^{53} \mathrm{As}$ such, the ICJ and the ITLOS potentially have jurisdiction over disputes arising under several other conventions, including the 1993 FAO Compliance A greement, ${ }^{74}$ the 1995 U.N. Convention on Straddling and Highly M igratory Fish Stocks (FSA), ${ }^{55}$ or the 2001 Convention on the Protection of the U nderwater Cultural Heritage. ${ }^{56}$ Further, the FSA has a cascading effect by providing in its A rticle 30.2 that LOSC Part XV applies mutatis mutandis to any dispute concerning the interpretation or application of a regional or global agreement relating to straddling or highly migratory stocks, such as the 2000 Convention on the Conservation and $M$ anagement of Highly M igratory Fish Stocks in the Western and Central Pacific Ocean. ${ }^{57}$ That effect only exists, however, if the Parties to the dispute are Parties to both the FSA and the relevant regional or global fisheries agreement. ${ }^{58}$ Parties concluding new treaties on maritime

\footnotetext{
${ }^{49}$ Ibid., A rt. 297.1.a.

50 Ibid., A rt. 297.3.a.

${ }^{51}$ Ibid., A rt. 298.

52 ITLOS Statute, Art. 21.

${ }^{53}$ LOSC, A rt. 288.2; see, T T reves, 'A System for Law of the Sea Dispute Settlement' in David Freestone, $R$ Barnes and DM Ong (eds), The Law of the Sea (OUP 2006) 417.

${ }^{74}$ A greement to Promote Compliance with International Conservation and $M$ anagement $M$ easures by Fishing V essels on the High Seas, 24 N ovember 1993, 33 I.L.M. 968.

${ }^{55}$ A greement for the Implementation of the Provisions of the U nited N ations Convention on the Law of the Sea of 10 December 1982 R elating to the Conservation and M anagement of Straddling Fish Stocks and Highly M igratory Fish Stocks (1995) A rt. 30.2, 2167 U.N.T.S. 88, 34 I.L.M . 1542.

${ }^{56}$ Convention on the Protection of the Underwater Cultural Heritage 2001, 41 I.L.M . 40.

${ }^{57}$ Convention on the Conservation and $\mathrm{M}$ anagement of Highly M igratory Fish Stocks in the Western and Central Pacific Ocean 2000, 40 I.L.M . 278.

${ }^{58} \mathrm{~T}$ M cD orman, 'A $\mathrm{n}$ Overview of International Fisheries Disputes and the International Tribunal for the Law of the Sea', (2002) 40 Canadian Y bk Intl L 119. Even so, as noted above, important EEZ activities may be excluded from compulsory dispute settlement.
} 
matters also may provide for referral of disputes to the ITLOS or the ICJ, as may be seen in the 1993 A greement to Promote Compliance with International Conservation and Management M easures by Fishing V essels on the High Seas. ${ }^{59}$ Finally, A rticle 22 of the ITLOS Statute allows parties to earlier treaties concerning the LOSC, such as MARPOL $1973 / 78,{ }^{60}$ to submit their disputes arising under those treaties to the ITLOS.

The WTO Appellate Body has considerable breadth in its jurisdiction over any disputes arising under the GA TT and its annexes, to which more than 150 States are Parties. ${ }^{61}$ Four annexes contain agreements addressing trade in goods, services, aspects of intellectual and property rights as well as 'plurilateral agreements' addressing certain sectors and government procurement. Disputes concerning these 'covered agreements' are addressed in the first instance through arbitral dispute panels; their decisions, called 'reports', can be appealed to the A ppellate B ody.

\section{5) Final and Binding Decisions}

These inter-State judicial bodies render decisions that are regarded as final (except as noted below) and as legally binding.

Judgments issued by the ICJ in contentious cases are final, without further appeal and binding on the Parties, ${ }^{62}$ including those rendered pursuant to the LOSC. ITLOS decisions are also final and binding on the Parties. ${ }^{63}$ Decisions of the WTO Appellate Body are binding on the Parties, but they technically are not final; they must be adopted by the Dispute Settlement Body (DSB), a WTO organ that is essentially the WTO's plenary General Council operating under a different name and in accordance with special rules. Though not final, when an arbitral panel or the A ppellate B ody's report is placed before the DSB, the report will be adopted and become binding, unless there is a consensus of the DSB not to do so (the process is known as 'reverse consensus'). ${ }^{64}$ Since normally the Party that prevailed before the A ppellate B ody will block any such consensus, the likelihood of the A ppellate B ody's decision not being adopted is extremely low and to date has not happened.

A s of the end of 2011, 152 cases had been filed with the ICJ, leading to the issuance of 77

\footnotetext{
${ }^{59} \mathrm{~A}$ greement to Promote Compliance with International Conservation and $\mathrm{M}$ anagement $\mathrm{M}$ easures by Fishing $\mathrm{V}$ essels on the High Seas (1993) A rt. 9,, FA O Res. 15/93, 33 I.L.M. 968.

${ }^{60}$ International Convention for the Prevention of Pollution from Ships 1973, 1340 U.N.T.S. 184, 12 I.L.M. 1319, as amended.

${ }^{61}$ DSU, Art. 1.

${ }^{63}$ LOSC, A rt. 296; ITL OS Statute, A rt. 33.

${ }^{64}$ DSU, Arts. 6.1, 16.4, 17.14, 22.6.
} 
binding judgments and 26 advisory opinions. From 1996 to 2012, 19 cases were submitted to the ITLOS, leading to the issuance of several orders on the provisional release of vessels and crew, one judgment on maritime delimitation and one advisory opinion. Hundreds of 'consultations' have been pursued as a first step in WTO dispute settlement and, as of the end of 2011, 402 disputes have been filed, leading to the adoption of 176 panel decisions and 108 A ppellate Body decisions. ${ }^{65}$ Determining whether the decisions reached in those cases have resulted in compliance can be complicated, but in many instances compliance is forthcoming. ${ }^{66}$

If compliance is not forthcoming, the relevant treaties for the ICJ, ITLOS and WTO A ppellate Body generally do not provide that their decisions are enforceable in national courts, although such enforcement may occur under national law. With respect to the ICJ, each U.N. $M$ ember State 'undertakes to comply with the decision of the International Court of J ustice in any case to which it is a Party'. ${ }^{67}$ If that does not happen, the recourse envisaged by the U.N. Charter is for the victorious Party to appeal non-compliance to the U.N. Security Council, 'which may, if it deems necessary, make recommendations or decide upon measures to be taken to give effect to the judgment'. ${ }^{68}$

The LOSC does not compel enforcement in national courts of ITLOS decisions as among States, except with respect to disputes relating to the deep seabed. For those disputes, any LOSC dispute settlement body decision concerning 'the rights and obligations of the A uthority and of the contractor shall be enforceable in the territory of each State Party' ${ }^{69}$ and decisions of the Seabed Disputes Chamber are 'enforceable in the territories of the States Parties in the same manner as judgments or orders of the highest court of the State Party in whose territory the enforcement is sought'. ${ }^{70}$

Similarly, the Uruguay Round agreements do not oblige States to allow litigation in national courts for enforcement of the agreements, including enforcement of Panel or A ppellate

\footnotetext{
${ }^{65}$ For up-to-date information on the case-law, see the relevant Internet sites: ICJ <http:www.cij-icj.org>; ITLOS $<$ <ttp://www.itlos.org>; WTP A ppellate Body <http://www.wto.org>.

${ }^{66}$ See, e.g. C Schulte, Compliance with D ecisions of the International Court of J ustice (OUP 2004) (finding that most ICJ decisions result in compliance); B Wilson, 'The WTO Dispute Settlement System and Its Operation: A B rief Overview of the First Ten Y ears' in R Y erxa and B W ilson (eds), Key Issues in WTO Dispute Settlement: The First Ten Years (CUP 2005) 24 (finding that WTO members have 'showed great respect for the decisions emanating from the panels and the A ppellate B ody, even where they strongly disagreed with those decisions').

${ }^{67}$ U.N. Charter, Art. 94.1.

${ }^{68}$ Ibid., A rt. 94.2.

${ }^{69}$ LOSC, A nnex III, A rt. 21.2.

${ }^{70}$ IT L OS Statute, Art. 39.
} 
Body reports. ${ }^{71}$ Indeed, although the reports find a violation of international law, they only 'recommend that the member concerned bring the measure into conformity with that agreement' ${ }^{72}$ The remedies contemplated are that the State will terminate its w rongful action within a reasonable period of time or, failing that, will pay compensation for the harm it continues to cause by that action. In the absence of doing so, the other State's remedy is seek authorization from the Panel to suspend its own concessions to the violating State - in essence, authorized retaliation. ${ }^{73}$

III) SHIFTING TERRAIN

Chapter $[X X]$ of this volume discusses in some depth the history of international adjudication. For present purposes, a shift in emphasis during the past 20 years is discernible with respect to judicial bodies for resolving disputes between States. When establishing the $\mathrm{PCIJ}$ in 1922 and the ICJ in 1945, the model of 'international court' was selected, with an almost exclusive focus on litigation by States. M ore recent structures, such as dispute settlement under the 1982 LOSC and at the WTO, have sought to accommodate more complex forms of adjudication, allowing or requiring States to use arbitration. The drafters of the LOSC neither selected an existing inter-State court (ICJ) nor created a new inter-State tribunal (ITLOS) as the sole venue for compul sory dispute settlement. Instead, they opted for a menu of potential options, with the default being inter-State arbitration. For the WTO, the initial proceedings are arbitral in nature; only after issuance of the Panel's decision can the matter be appealed to the WTO A ppellate Body. These developments are no doubt influenced by the burgeoning use of arbitration in commercial, trade and investment disputes against States.

Moreover, more recent inter-State processes evince some greater sensitivity to the accommodation of non-State actors in the dispute settlement process. A s previously discussed, the ITLOS Seabed Disputes Chamber is capable of hearing disputes involving natural or juridical persons - there is no need for the government of those persons to bring a claim on their behalf and non-governmental organizations may appear as amicus curiae in ITLOS advisory opinion proceedings. Although non-State Parties do not appear before the WTO Appellate Body, opportunities exist for the filing of amicus briefs by such actors. ${ }^{74}$ Even the ICJ in recent years has

\footnotetext{
${ }^{71}$ See, e.g. 19 U.S.C. § 3512.c.1 (2006).

${ }^{72}$ DSU, Art. 19.1.

${ }^{73}$ See, J Jackson, 'International Law Status of WTO Dispute Settlement Reports: Obligation to Comply or Option to 'Buy Out'?' (2004) 98 A m. J. Int'I L. 109.

${ }^{74}$ See, V D onaldson, 'The A ppellate B ody: Institutional and Procedural A spects' in PFJ M acrory, AE Appleton and
} 
allowed Parties to appear before it (Palestine, Kosovo) that do not fit the mold of the typical State Party. Even so, the traditional approach of 'only States' remains largely intact. W hen Y ugoslavia brought suit at the ICJ against NATO States concerning the 1999 aerial bombing campaign relating to Kosovo, Y ugoslavia had to file 10 cases against individual NATO members, as there was no means for suing NATO directly. Similarly, when NATO allowed Greece to block M acedonia's accession to NATO in 2008, M acedonia was only able to file its case against Greece. Although $M$ acedonia successfully proved that Greece wrongfully blocked $M$ acedonia's accession to NATO, the Court's decision had no direct effect on NATO. Even as of the mid-1990's, former IC) President Sir Robert Jennings viewed the Court's narrow jurisdiction in this regard as an unfortunate and anomal ous artifact, largely out-of-step with contemporary needs. ${ }^{75}$

The difficulty for these courts and tribunals to accommodate the rise of non-State actors as important players in the creation, interpretation and enforcement of international law raises an important question: are these bodies relics of the past, incapable of keeping up with the complex and ever-changing domain of international law? Observers note that these judicial bodies have relatively modest case-loads, with the ICJ averaging about a dozen cases on its docket at any given time and the ITLOS only a few. Even when taking account of the limited number of States (as of 2012, there are 193 U .N. M ember States) among whom disputes might be litigated, and taking into consideration that a tribunal such as the ITLOS is only one of several options for dispute settlement, critics still maintain that such judicial bodies are significantly under-utilized. While there are reasons to regard inter-State courts and tribunals as having a much less dominant role in the realm of contemporary international adjudication than they used to enjoy, ${ }^{76}$ they still serve important and indispensable systemic functions.

IV) SYSTEMIC FUNCTIONS SERVED BY THESE JUDICIAL BODIES

\section{1) Promoting the Conclusion of Major Sectoral Agreements}

A $n$ initial reason for why inter-State judicial bodies remain an important component of the international system is that they continue to be viewed as such by States. Despite the rise of other mechanisms for international adjudication, inter-State courts or tribunals continue to be a valuable

MG Plummer (eds), I The World Trade Organization: Legal, Economic and Political Analysis (Springer 2005) 1332-33.

${ }^{75}$ RY J ennings, 'T he U nited N ations at Fifty: The International Court of J ustice A fter Fifty Y ears' (1995) 89 A m. J. Int'l L. 493.

${ }^{76}$ See, K A Iter, 'Private Litigants and the N ew International Courts' (2006) 39 Comp. Pol. Stud. 22. 
option when concluding important multilateral agreements.

Thus, when bringing to conclusion the principal treaty on the law of the sea in 1982, States regarded it as important to establish the ITLOS (composed of persons with recognized competence in the field of the law of the sea) and to use the ICJ as potential options for compulsory dispute settlement. Inter-State arbitration was included in the mix, but such a dispute settlement mechanism was not regarded by all States as sufficient; some States wanted a more formal, judicial option. ${ }^{77}$ Though not limited to inter-State courts or tribunals, the overall system of LOSC dispute settlement - including the establishment of the ITLOS - was viewed throughout the negotiations of the LOSC as a critical component for moving beyond unilateral exercises of power over maritime areas. As key U.S. negotiators asserted early in the process: 'In the broadest sense, the purpose of the law of the sea negotiations is to put an end to the direct relationship that such a system entails between the enjoyment of a right and the application of power. A system of compulsory, impartial, third-party adjudication is thus an essential element of the overall structure'.$^{78}$ Likewise, A lan B oyle notes that the 'main object of the LOS Convention's scheme for compulsory jurisdiction is to guarantee the integrity of the Convention and to act as a restraint or moderating influence on the excessive claims and tensions likely to arise over time'. ${ }^{79} \mathrm{~J}$ ohn N oyes argues that 'States likely perceive that the threat of adjudication will constrain unreasonable unilateral interpretations of substantive Convention provisions'.$^{80}$

Further, most States apparently regarded the availability of compul sory dispute settlement as critical to the successful completion of negotiations because ambiguities in the text not resolved through negotiation would require resolution by an authoritative third-party. The first President of the negotiating conference, Hamilton Shirley A merasinghe, observed in 1976 that: 'the provision of effective dispute settlement procedures is essential for stabilizing and maintaining the compromises necessary for the attainment of agreement on a convention. [Without such procedures,] the compromise will disintegrate rapidly and permanently' ${ }^{81}$

\footnotetext{
${ }^{77}$ See, JE N oyes, 'Compulsory Third Party A djudication and the 1982 U nited Nations Convention on the Law of the Sea' (1989) 4 Conn. J. Int'I L. 675, 685 ('the politics of the negotiations were such that insistence on only one or two forums would have meant a lack of consensus on including provisions for binding adjudication in the text of the Convention').

${ }^{78}$ J R Stevenson and BH Oxman, 'The Preparations for the L aw of the Sea Conference' (1974) 68 A m. J. Int'I L. 1, 31. ${ }^{79}$ B oyle, 'Problems of Compulsory J urisdiction and the Settlement of Disputes Relating to Straddling Fish Stocks' (1999) 14 Int'l I. M arine \& Coastal L. 1, 6.

${ }^{80}$ N oyes, supra note 77 , at 683.

${ }^{81}$ Quoted in ibid., at 682.
} 
Likewise, when negotiating the principal treaties to establish the WTO, States regarded it as important to create an inter-State tribunal - the WTO A ppellate B ody - charged with promoting unified interpretations of the relevant agreements. As J ohn Jackson has observed, 'the GATT contracting parties resolved at the 1986 launching meeting of the U ruguay Round (at Punta del Este) to deal with some of the defects and problems of existing dispute settlement rules' ${ }^{82}$ The negotiators ultimately concluded that the 'negotiation-oriented' approach to dispute resolution characteristic of the GATT was no longer tenable; less powerful States were unwilling to participate in an ambitious new system of trade rules if dispute resolution could be dominated by the negotiating strength of powerful States. Consequently, the turn was made to a more 'judicialized' and 'rules-oriented' approach to dispute resolution. ${ }^{83}$ In setting up that system, arbitration was fine for the initial round of dispute resolution, but only if the arbitral decisions could be appealed to a more permanent, court-like body capable of maintaining uniformity in interpretation and application of the law. In short, establishing a dispute settlement system capped by an inter-State tribunal helped bring to a conclusion the U ruguay R ound negotiations.

Despite the rise of other possibilities, the ICJ also remains a desirable forum to select for inter-State dispute resolution when concluding contemporary multilateral treaties, such as the 1999 International Convention for the Suppression of the Financing of Terrorism, ${ }^{84}$ the 2001 Convention on Persistent Organic Pollutants ${ }^{85}$ or the 2003 U.N. Convention against Corruption. ${ }^{86}$ If negotiators wish to include binding dispute resolution as one element of a major multilateral treaty, the ICJ is one obvious, respected and impartial forum to select.

In short, notwithstanding whatever flaws that may exist with inter-State courts and tribunals, such forums are viewed as an important component when concluding major multilateral agreements. Though other venues have emerged for the resolution of certain kinds of disputes,

\footnotetext{
82 Jackson, supra note 65, at 134; see generally, 'Dispute Settlement M echanisms' in TP Stewart (ed), The GATT U ruguay Round: A Negotiating History (1986-1992) (K luwer Law and Taxation 1993) 2663.

${ }^{83} \mathrm{JH}$ Jackson, The World Trading System: Law and Policy of International Economic Relations (M IT Press 1997) 107-37; see, PL Chang, 'The Evolution and Utilization of the GATT/WTO Dispute Settlement Mechanism' in JC Hartigan (ed), Trade Disputes and the Dispute Settlement Understanding of the WTO: An Interdisciplinary Assessment (Emerald Group 2009) 92 ('Although not immune from the influence of power politics, the WTO procedure, given its more automatic and rule-based structure, leaves less room for power play. The procedure has established itself as the norm for resolving trade conflicts in the international community'.).

${ }^{84}$ International Convention for the Suppression of the Financing of Terrorism 1999, A rt. 24.1, T.I.A.S. 13075, 2178 U.N.T.S. 197.

${ }^{85}$ Stockholm Convention on Persistent Organic Pollutants 2001, A rt. 16.2, 2256 U.N.T.S. 119.

${ }^{86}$ U.N. Convention A gainst Corruption 2003, A rt. 66.2, 2349 U.N.T.S. 41.
} 
inter-State courts and tribunals retain certain comparative advantages when considering where an interpretive dispute under the agreement might be brought, including broad subject matter jurisdiction, global membership and an attractiveness to States precisely because non-State actors are largely not present. Though habitual resort to these courts or tribunals to vindicate rights under the multilateral agreement is not apparent, the actual use of the forum may be secondary to its availability for use.

\section{2) Promoting Negotiated Resolution of Disputes}

The availability of inter-State courts and tribunals, especially for compulsory adjudication, also provides a useful 'shadow' when a dispute arises between States, encouraging them to negotiate an out-of-court resolution. For this reason, a metric by which one assesses the utility of inter-State judicial bodies solely based on the number of cases before those courts misses the effect that their existence has in conditioning State behavior ab initio when the dispute arises. A nytime a State embarks on a major policy initiative, one question for that State will be whether the action violates the State's obligations under international law and, if so, whether other States will react in an adverse manner. If such reactions include the possibility of a highly visible resort to dispute resolution, such as at the ICJ, the ITLOS or the WTO Appellate Body, then it serves as a disincentive for the State to pursue its policy initiative and an incentive to pursue other, legally-available options.

Empirically establishing and measuring this 'deterrence factor is difficult, since it involves proving that a State did not act in a certain way due to the presence of potential litigation at an inter-State court or tribunal. N everthel ess, it appears to be the case that most disputes arising under agreements for which inter-State courts or tribunal are available, such as the law of the sea, are resolved through negotiation ${ }^{87}$ and, further, 'it is conceivable that in some cases the parties have settled a dispute consensually because of a desire to avoid compulsory settlement' under the Convention. ${ }^{88}$

An example of the phenomenon may be seen in the Swordfish Stocks case, which arose after Chile imposed a port ban on Spanish vessels that were fishing swordfish near Chile's EEZ. The European Community initiated dispute resolution before the WTO, after which Chile initiated

\footnotetext{
${ }^{87}$ T M cD orman, 'Global O cean Governance and International A djudicative Dispute Resolution' (2000) 430 cean \& Coastal M anagement 255, 257.

${ }^{88} \mathrm{R}$ Churchill, supra note 53 , at 388, 390, 414.
} 
proceedings at the ITLOS. The dispute was then resolved by negotiation before hearings went forward in either venue. In filing their cases, both sides signaled the seriousness with which they took the dispute and raised the prospect of an inter-State court or tribunal resolving the matter, which entailed uncertainty in the outcome. In light of that, the two sides instead chose to resolve the matter as between themselves, negotiating and compromising in the shadow of potential third-party inter-State court/tribunal dispute resolution. ${ }^{89}$

\section{3) Promoting and Protecting a C oherent L egal System}

Inter-State judicial bodies provide a unique service by acting as the promoter and guardian of the system of international law in which they operate, capable of providing authoritative action that speaks to the broader functioning and stability of the international legal system than is the case for arbitral or other forums. This role may be seen in three discrete functions.

(a) Promoting Stability and P redictability in Inter-State Relations

A paradox in the operation of inter-State courts and tribunals is that, while it is generally accepted that their decisions only bind the two Parties that appear before them in any given case, it is also generally accepted that the decision reached has ramifications that extend well beyond those two Parties. Thus, when the ICJ decides that particular conduct by a State $X$ violates, for example, the $\mathrm{V}$ ienna Convention on Consular R elations, the decision speaks not just to State $\mathrm{X}$ but al so to State $Y$ if the latter were to engage in essentially the same conduct. M oreover, while there is little doubt that if State $Y$ were brought before the ICJ, it would receive a comparable finding, it also appears that a comparable finding would be issued if State $Y$ were brought before any other international dispute forum. As Shabtai R osenne has observed:

While there is no formal hierarchy of international courts and tribunals, the pre-eminence of the Permanent Court and the present International Court is today generally accepted. A ny other international adjudicatory body which ignored relevant dicta and decisions of the International Court would jeopardize its credibility. The constant accretion of judicial precedents is creating what is now a substantial body of international case-law. ${ }^{90}$

As such, even if State $Y$ could not be itself brought before the ICJ, the decision rendered by the ICJ against $S$ tate $X$ makes it easier for other States to argue authoritatively that State $Y$ may not engage in such action. That same observation is equally applicable to other inter-State courts and

\footnotetext{
${ }^{89}$ M A Orellana, 'The Swordfish Dispute B etween the EU and Chile at the ITLOS and the WTO' (2002) 71 N ordic J. Int'I L. 55, 65.

${ }^{90}$ S Rosenne, The Law and Practice of the International Court, 1920-1996 (M artinus Nijhoff 1997) 1609.
} 
tribunals, such as ITLOS and the WTO A ppellate B ody, but it is not true of ad hoc arbitral panels, which often disagree as among themselves when addressing comparable issues of international law. ${ }^{91}$

A broader ramification with respect to the ICJ's decision is that it adds a further building block to the development of a coherent system of law, with its decisions often influencing the development of new treaty regimes and then refining those treaty regimes through subsequent interpretations. A n example of this phenomenon may be seen with respect to the law of the sea. Over the past century, there can be little doubt that the decisions of the $\mathrm{PCI}$ and ICJ concerning fishing, transit and maritime boundaries have had an enormous effect on the formation of a comprehensive and organized law of the sea, beginning with the 1958 treaties and continuing up through the emergence of the LOSC and related treaties. ${ }^{92}$ This influence appears set to continue with decisions by the ICJ and the ITLOS, supplemented by LOSC arbitral panels, in interpreting the meaning of these regimes. As A lan B oyle asserts, 'the principal purposes of the Convention's provisions on dispute settlement are to provide authoritative mechanisms for determining questions relating to 'interpretation or application' of the treaty, to guarantee the integrity of the text and to control its implementation and development by States parties' ${ }^{93}$

$Y$ et there is a further ramification as well. The basic reasoning employed by the international court or tribunal - what matters and what does not matter in pursuing an authoritative decision - has a broad conditioning effect on the way States themselves engage in legal reasoning, thereby promoting greater harmony and predictability in inter-State legal reasoning. Petros Mavroidis explains the phenomenon in his discussion of the WTO Appellate Body (AB), but the explanation is equally applicable to the ICJ or the ITLOS:

The $A B$ is there not only to solve a particular dispute but also to make the adjudication of similar future transactions (more) predictable. It is not that the outcome (winner/loser) does not matter, it does. But ... [so does] ... the thought pattern that the A B will employ in order to respond to the questions submitted to it. The process, in other words, is as important as, if not more important, than the outcome. ${ }^{94}$

Inter-State courts and tribunals have been instrumental in helping solidify the fabric of

${ }^{91}$ See, e.g. JA M aupin, 'M FN -based J urisdiction in Investor-State A rbitration: Is There A ny Hope for a Consistent Approach?' (2011) 14 J. Int'l Econ. L. 157.

${ }_{92} \mathrm{See}, \mathrm{S}$ Oda, 'The International Court of J ustice V iewed from the B ench (1976-1993)' (1993) 244 Recueil des Cours 9, 127-55.

${ }_{93}$ B oyle, supra note 35 , at 38-39.

${ }^{94} \mathrm{M}$ avroidis, supra note 83 , at 81 . 
international law, carefully and judiciously explaining broad but core matters such as: the rules on sources of international law; the background or 'secondary' rules of State responsibility; the nature of States, international organizations and other actors in the international system; and how to reconcile conflicts between different areas of law, on both the international plane and between the international and national planes. No other dispute resolution forum is comparably situated to perform this function.

(b) Advisory O pinions on 'C onstitutional' Issues

Inter-State judicial bodies can also serve an important function by rendering advisory opinions that can help structure core areas of the law within their domain, serving almost as 'constitutional' courts for the whole international legal system. Thus, separate from the ICJ's jurisdiction over contentious cases between two States, the Court also has jurisdiction to issue advisory opinions on legal questions, which can address rudimentary issues about the actors and processes of international law. This advisory jurisdiction of the ICJ may only be invoked by U.N. organs and by the specialized agencies of the U nited Nations who have been authorized to do so. The ITLOS al so has advisory jurisdiction, though it is more narrowly focused on certain aspects of the LOSC and related agreements. Specifically, the Seabed Disputes Chamber of ITLOS may give advisory opinions at the request of the Assembly or the Council of the International Seabed A uthority, ${ }_{100}$ while the ITLOS may advise on any legal question where an international agreement related to the convention specifically provides for such an opinion. ${ }^{101}$ The WTO A ppellate Body has no advisory jurisdiction.

Although advisory opinions are not legally binding - they are, after all, 'advisory' - they invariably project juridical authority by legitimating certain conduct of States and organizations and by filling in gaps in a system where judicial precedents are relatively scarce. ${ }^{95}$ To name just a few: the ICJ's 1949 advisory opinion on Reparations for Injuries helped secure the status of international organizations as 'subjects' of international law; ${ }^{96}$ its 1951 advisory opinion on Reservations to the $\mathrm{G}$ enocide Convention served as an important forerunner to contemporary law

\footnotetext{
101 ITLOS Rules, Art. 138.

${ }^{95}$ See, M M Aljaghoub, The Advisory F unction of the International Court of J ustice 1946-2005 (Springer 2006); G Oduntan, The Law and Practice of The International Court of J ustice (1945-1996): A Critique of the Contentious and Advisory J urisdictions (Fourth Dimension 1999).

${ }^{96}$ Reparation for Injuries Suffered in the Service of the U nited Nations (A dvisory O pinion) 1949 I.C.J. 174.
} 
on treaty reservations; ${ }^{97}$ and its 1962 Certain Expenses advisory opinion was instrumental in clarifying the power of the U.N. General A ssembly to deploy peacekeeping missions, the legal obligation of States to support them and the role of the A ssembly vis-à-vis the Security Council in matters of peace and security.$^{98}$ In 2011, the Seabed Disputes Chamber of ITLOS issued its first advisory opinion, which importantly clarified that a State that sponsors contractors who engage in exploratory activities on the deep seabed is responsible for supervising them and, in doing so, must engage in a precautionary approach, must use best environmental practices and must conduct environmental impact assessments. ${ }^{99}$

(c) Interim Measures of P rotection

A third way that inter-State judicial bodies serve as a guardian of the system in which they operate is by issuing interim measures of protection in situations where immediate action is needed to prevent irreparable harm on a matter relevant to the filed case. Although judicial proceedings generally are time-consuming, the procedures for interim measures of protection are expedited, measured in days, not weeks or months. M oreover, greater leew ay typically is given to the court or tribunal to issue such provisional measures, even if the court or tribunal is later found to have no jurisdiction over the merits of the case. Of course such measures may also be permitted to arbitral tribunals, but the permanent existence of international courts and tribunals provides them a comparative advantage, for it allows immediate action without any delay caused by the appointment and convening of adjudicators.

The ICJ has received about 40 requests for interim measures of protection. As a general matter, the Court is willing to issue such measures so long as a prima facie showing of jurisdiction exists, the requested measure is linked to the underlying case before the Court and irreparable harm is likely in the absence of the issuance of the requested measure. ${ }^{102}$ In recent cases, the Court al so has stated that it 'may exercise this power only if it is satisfied that the rights asserted by a party are at least plausible'. ${ }^{103}$ Further, the Court has found that an order on provisional measures

\footnotetext{
${ }^{97}$ Reservations to the Convention on the P revention and Punishment of $G$ enocide (A dvisory O pinion) 1951 I.C.J. 15.

${ }^{98}$ Certain Expenses of the U nited Nations (Article 17, Paragraph 2, of the Charter) (Advisory Opinion) 1962 I.C.J. 151.

${ }^{99}$ Responsibilities and Obligations of States Sponsoring Persons and Entities with Respect to Activities in the A rea, supra note 35, at paras 121-50, 242.

${ }^{102}$ See, ICJ Statute, A rt. 41; see generally, S Oda, 'Provisional M easures: The Practice of the International Court of J ustices', in V L owe and M Fitzmaurice, F ifty Years of the International Court of J ustice (CUP 1996) 541.

${ }^{103}$ See, e.g. Request for Interpretation of the J udgment of 15 J une 1962 in the Case Concerning the Temple of Preah Vihear (Cambodia v. Thailand) (Provisional M easures) 2011 ICJ Gen. List 151, para 33.
} 
is binding upon the States to whom it is directed. ${ }^{104}$

The ITLOS may also issue binding provisional measures of protection, if 'appropriate under the circumstances to preserve the respective rights of the parties to the dispute or to prevent serious harm to the marine environment, pending the final decision'. ${ }^{105}$ M oreover, ITLOS may receive applications for the prompt release of a detained vessel or its crew where the authorities of a State have detained a vessel or crew flying the flag of another State and it is alleged that the detaining State did not act in compliance with the LOSC. ${ }^{106}$ Such applications may only be made by or on behalf of the vessel's flag State. ${ }^{107}$ While the relevant States can choose to take the provisional measures or a prompt release proceeding before some other LOSC dispute resolution forum, ITLOS remains the 'default' tribunal. In other words, it matters not whether the responding State selected the ITLOS for binding dispute resolution when it joined the LOSC; unless the Parties select some other fora for these two types of proceedings, the responding State may be brought before the ITLOS.

The WTO A ppellate B ody does not have the power to issue interim measures of protection, nor do WTO arbitral panels, largely because of the nature of the violations at issue (denial of trade benefits) and the relatively speedy process at the WTO for resolving the dispute on the merits.

\section{4) Authoritative R esolution of Important Disputes}

Sometimes lost in the discussion of inter-State courts and tribunals is that, while their dockets are not extensive, they often include extremely important disputes for those States involved. For example, Nicaragua's case against the U nited States in the mid-1980's before the ICJ was a critical component of its foreign policy, as was Macedonia's case against Greece in this century. An inter-State court or tribunal can provide a well-known and respected forum for addressing major grievances; while resort to that forum may be rare, when it occurs the stakes can be high. While the numerous land and boundary delimitation cases before the ICJ do not attract much global notice, they typically concern important bilateral disputes that, left to fester, might well lead to armed conflict.

Likewise, the jurisprudence of the WTO A ppellate Body is incrementally solidifying the

\footnotetext{
${ }^{104} \mathrm{LaG}$ rand Case (Germany v. U nited States) (J urisdiction) 2001 ICJ 466.

${ }^{105}$ LOSC, A rt. 290.

${ }^{106}$ Ibid., A rt. 292. The relevant provisions of the LOSC call for the prompt release of the vessel or its crew upon the posting of a reasonable bond or other financial security.

107 See, S Rosenne, Provisional Measures in International Law: The International Court of Justice and the International Tribunal for the Law of the Sea (OUP 2005).
} 
meaning of key global trade agreements as they apply in bilateral trade relations, which in turn is influencing national decision-making and national laws. ${ }^{108}$ Resort to WTO dispute settlement is a highly-public affair, taken by a government for the purpose of protecting key sectors of a State's economy from allegedly unfair and unlawful trade practices, involving goods, services, intellectual property, government procurement and a range of other matters. Even in the early years of the WTO, John Jackson noted that the 'addition of the right to appeal to an A ppellate Body made up of a permanent cadre ... in conjunction with the automatic approval of panel reports, has already had a very profound impact on the world trading system as embodied in the GATT and WTO' ${ }^{109}$

The ITLOS, the youngest of the three inter-State courts discussed here, has attracted the least use, in part because it competes with other dispute settlement fora. Nevertheless, it too has addressed important disputes, most recently the maritime boundary delimitation between Bangladesh and $M$ yanmar, the first judgment of an international court or tribunal to delimit the continental shelf beyond 200 nautical miles from the coast. ${ }^{110}$

\section{V) DECLINE AND FALL?}

In considering whether inter-State judicial bodies are becoming relics, it is worth considering whether their role has really changed in recent years. Such courts and tribunals were never a dominant feature of international dispute settlement in terms of caseload or exposure of States to compulsory jurisdiction; there was never a 'golden era' of habitual resort to these courts or tribunals for all disputes arising amongst States. If anything, the number of cases before these courts or tribunals has significantly increased as measured against 50 or even 25 years ago. Concomitantly, there has been a very significant increase in the establishment and use of other forms of transnational dispute settlement before institutions such as the ICSID, but that burgeoning practice has not collaterally diminished the resort to inter-State courts or tribunals.

A rguably the 'rising tide' of resort to international adjudication is raising all of the dispute settlement 'boats', including those consisting of inter-State courts and tribunals. A the same time, the emergence of 'blended' models when creating new courts and tribunals - in which there exists

\footnotetext{
${ }^{108}$ WJ Davey, 'The WTO Dispute Settlement System: The First Ten Y ears' (2005) 8 J. Int'I Econ. L. 17.

${ }^{109} \mathrm{~J}$ ackson, supra note 65 , at 180.

${ }^{110}$ Delimitation of the M aritime Boundary in the Bay of Bengal (Bangladesh/M yanmar), (J udgment) 2012 ITLOS Case No. 16.

<http://www.itlos.org/fileadmin/itlos/documents/cases/case_no_16/C16_Judgment_14_03_2012_rev.pdf > accessed 20 December 2012.
} 
an option for resort to a court or an arbitral body (e.g. under the LOSC) or an arbitral body from which appeal may be made to a court/tribunal (e.g. the WTO) - may reflect an effort to respond creatively to new challenges facing States in a changing world. What has not changed are the functions of inter-State judicial bodies, functions that cannot readily be supplanted by other forms of adjudication.

\section{Recommended Readings}

V aughan L owe \& M algosia Fitzmaurice, Fifty Y ears of the International C ourt of J ustice (CUP 1996).

J ohn J ackson, The J urisprudence of GATT and the WTO (CUP 2000).

P. Chandrasekhara Rao \& Rahmatullah K han (eds), The International Tribunal for the $L$ aw of the Sea: Law and Practice (K luwer 2001).

Natalie K lein, Dispute Settlement in the UN Convention on the Law of the Sea (CUP 2005).

Giorgio Sacerdoti, A lan Y anovich \& J an Bohanes (eds), The WTO at Ten: The Contribution of the Dispute Settlement System (CUP 2006)

Gregory C. Shaffer \& Ricardo M elendez-Ortiz (eds), Dispute Settlement at the W TO: The Developing Country Experience (2010).

Christian Tomuschat, 'International Courts and Tribunals' in Rüdiger W olfrum (ed), M ax Planck Encyclopedia of Public International Law (OUP, online edition, last updated Feb. 2011), <www.mpepil.com> accessed 30 J une 2012.

Igor V. Karaman, Dispute Resolution in the Law of the Sea (M artinus Nijhoff 2012).

A ndreas Zimmermann, Christian Tomuschat $\&$ K arin Oellers-Frahm (eds), The Statute of the International Court of J ustice: A Commentary (OUP 2012). 